\title{
Impact of infrastructure on socio-economic development of Russian regions: methodology and analysis
}

\author{
E.D. Ignatieva ${ }^{1} \bowtie$, O.S. Mariev ${ }^{1,2}$, A.Ye. Serkova ${ }^{1}$ \\ ${ }^{1}$ Institute of Economics of the Ural Branch of the Russian Academy of Sciences, Yekaterinburg, Russia; e-mail: elen_i99@mail.ru \\ ${ }^{2}$ Ural Federal University, Yekaterinburg, Russia
}

\begin{abstract}
Relevance. Regional infrastructure development directly affects economic growth, social development and the quality of life. To identify the key areas of infrastructure development in Russian regions, it is necessary to develop a methodological approach to the analysis of the impact of infrastructure on socio-economic development, which determines the relevance of this study. Research objective. This study aims to improve the methodology of assessment of the role infrastructure plays in the socio-economic development of Russian regions. Data and methods. The analysis relies on a system of general and integral, static and dynamic indicators used to assess the current state and dynamics of infrastructure in regions. The analysis takes into account the structural and functional features of infrastructure. The proposed methodology comprises methods for obtaining comparative estimates of regional infrastructure development, which can be applied to compile regional rankings. The study also uses methods of econometric and K-means cluster analysis. Results. A comparative analysis of the infrastructure development of Russian regions allowed us to assess the infrastructural potential of these regions, the discrepancies in infrastructure development and compare the infrastructure-related characteristics of the leading lagging regions. The results of econometric analysis as well as cluster analysis of regions based on general and integral dynamic indicators are discussed. Conclusions. The methodological approach proposed by the authors has been tested by using the data on Russian regions. The analysis has revealed the most typical problems faced by Russian regions. These problems should be taken into account in strategic decision- and policy-making.
\end{abstract}

\section{KEYWORDS}

region, infrastructure,

infrastructure development, static and dynamic indicators, economy, quality of life, public-private partnership

\section{ACKNOWLEDGEMENTS}

This research was supported by the Institute of Economics of the Ural Branch of the Russian Academy of Sciences.

\section{FOR CITATION}

Ignatieva, E.D., Mariev, O.S., \& Serkova, A.Ye. (2020) Impact of infrastructure on socio-economic development of Russian regions: methodology and analysis. R-economy, 6(2), 65-73. doi: 10.15826/recon.2020.6.2.006

\section{Влияние инфраструктуры на социально-экономическое развитие регионов России: методология и анализ}

\author{
Е.Д. Игнатьева ${ }^{1} \bowtie$, O.С. Мариев ${ }^{1,2}$, А.Е. Серкова ${ }^{1}$ \\ ${ }^{1}$ Институт экономики Уральского отделения Российской академии наук, Екатеринбург, Россия; \\ e-mail:elen_i99@mail.ru \\ 2 Уральский федеральный университет, Екатеринбург, Россия
}

\section{АННОТАЦИЯ}

Актуальность. Развитие региональной инфраструктуры напрямую влияет на экономический рост, социальное развитие и качество жизни. Для выявления ключевых направлений развития инфраструктуры в российских регионах необходимо разработать методологию, анализирующую влияние инфраструктуры на социально-экономическое развитие регионов. Цель исследования. Цель данного исследования - усовершенствовать методологию оценки роли инфраструктуры в социально-экономическом развитии регионов России. Данные и методы. Анализ основан на системе общих и интегральных, статических и динамических показателей, используемых для оценки текущего состояния и динамики инфраструктуры в регионах. Анализ учитывает структурные и функциональные особенности инфраструктуры. Предлагаемая методология включает в себя методы получения сравнительных оценок развития региональной инфраструктуры, которые можно применять для составления региональных рейтингов. В исследовании также используются эконометрические методы и кластерный анализ с помощью метода $k$-средних. Результаты. Сравнительный анализ развития инфраструктуры российских регионов позволил нам оценить (c) Ignatieva, E.D., Mariev, O.S., Serkova, A.Ye., 2020

\section{КЛЮЧЕВЫЕ СЛОВА}

регион, инфраструктура, развитие инфраструктуры, статические и динамические показатели, экономика, качество жизни, государственно-частное партнерство

\section{БЛАГОДАРНОСТИ}

Работа выполнена при поддержке Института экономики Уральского отделения Российской академии наук. 
инфраструктурный потенциал этих регионов, различия в развитии инфраструктуры и сравнить инфраструктурные характеристики регионов. Проинтерпретированы результаты эконометрического анализа, а также кластерного анализа регионов на основе общих и интегральных динамических показателей. Выводы. Предложенный авторами методологический подход апробирован с использованием данных по регионам России. Анализ выявил наиболее типичные проблемы, с которыми сталкиваются российские регионы. Эти проблемы должны учитываться при принятии стратегических решений и разработке государственной политики.

\section{ДЛЯ ЦИТИРОВАНИЯ}

Ignatieva, E.D., Mariev, O.S., \& Serkova, A.Ye. (2020) Impact of infrastructure on socio-economic development of Russian regions: methodology and analysis. R-economy, 6(2), 65-73. doi: 10.15826/recon.2020.6.2.006

\section{Introduction}

Comprehensive modernization of productive forces at the regional and macro-regional levels is impossible without infrastructure development. In order to monitor infrastructure development in Russian regions and adjust it to the needs of economic growth and to improve the quality of life in these regions, it is necessary to design the appropriate methodology.

The purpose of this article is to describe and substantiate the methodological approach to assessing the impact of regional infrastructure development on the socio-economic situation in the country. We are also going to describe the corresponding methodological principles and tools. Infrastructure influences all socio-economic processes in regions, creates conditions for the development of the real sector, helps improve the quality of life and provides opportunities for people's individual growth.

Our study focuses on the infrastructure in Russian regions and their socio-economic systems. A comprehensive approach should be applied to address the problems of infrastructure development in Russian regions, because the development of some types of infrastructure is associated with the development of other types of infrastructure. The high level of infrastructure development ensures the comparative advantages of regions in their interactions with each other and on a global scale.

\section{Literature review}

There are various approaches to analyzing and evaluating the impact of certain types of infrastructure on socio-economic development. Efimova (2009) identifies four main approaches to assessing the role of transport in regional development: by focusing on the availability of the market of resources and sales; by analyzing transport costs; by analyzing investment activity in the region; and by looking at the role of infrastructure factors in production and location decisions (the fourth approach also implies the use of entrepreneur surveys). Kazakova \& Pospelova (2017) compared the transport infrastructure in Russia with that of other countries and found its qualitative characteristics to be among the most significant limitations of economic growth. Wang et al. (2020) investigated the impact of transport infrastructure (railway and road) on the economic growth in the countries of the Belt and Road Initiative in 2007-2016.

Maliy \& Gusev (2010) assess the impact of energy enterprises on regional development by focusing on the case of Saratov region in Russia. A number of studies consider the impact of social infrastructure on the reproduction of human capital and the implementation of social projects (Tikhonovich, 2012; Roskruge, 2011; Wai et al., 2013). Tiwari (2008) discusses the impact of economic infrastructure on agricultural development, and Owualah (1987) on the development of small businesses. Chen \& Fang (2018) examined the relationships between economic growth, industrial electricity consumption and human capital by using a panel of 210 Chinese prefecture cities in 2003-2012.

Some studies apply instrumental methods and modeling: for example, Shvetsov et al. (2018) analyze the impact of infrastructure on regional socio-economic development (the case of the Nenets Autonomous Okrug) with the help of an autoregressive model with equations reflecting the dependence of endogenous indicators (GRP, R\&D costs, per capita income and volume of polluting emissions) on exogenous variables - factors of infrastructure. Cantos et al. (2005) use the production function to study the dependence of regional output on capital investment in transport infrastructure in Spanish regions. Kiselev \& Tkachev (2015) propose an economic and mathematical model for assessing the impact of social infrastructure on regional development. Malafeev \& Baskakova (2017) investigate the significance of infrastructure capital for the gross output of the material production sector by applying econometric analysis of panel data using Cobb-Douglas production function. 


\section{Types of infrastructure and their functions}

Our study aims to provide a comprehensive assessment of the impact that various types of infrastructure have on the socio-economic development of Russian regions. Such assessment can then be used for devising infrastructure development policies. The methodology of this study relies on the structural and functional aspects of infrastructure. Infrastructure has a fairly complex structure, including various industries, structures, facilities, and institutions. Infrastructure performs various economic, financial, demographic, social, environmental, and other functions. Infrastructure is a major factor that determines the economic and social prosperity of a region. For a more in-depth understanding of the impact of infrastructure, we should consider how specific types and element of infrastructure affect regional development (Ignatyeva et al., 2018).

There are three main types of regional infrastructure depending on its functions: productive-economic, financial and social. Productive-economic infrastructure, whose main function is to provide conditions for social production, includes transport, communications, electricity, and construction.

Transport infrastructure is an enabler for economic activity, an essential part of economic relations at the regional, interregional and global levels. According to Pchelintsev (2004), transport and communications contribute to the intensification and improvement of the quality of economic relations and ensure the mobility of production factors and the availability of production results. As the world practice shows, the presence of new infrastructural networks, including motor transport, is the most important competitive advantage of regions, a factor that is crucial for regions' general development and specialization, formation of local-scale territorial and industrial complexes and effective inter-regional interaction (Melnikovet et al., 2019).

Transport accounts for $8 \%$ of the industry structure of GRP. According to the data of the Federal State Statistic Service (Rosstat), fixed assets of transport at the end of 2018 accounted for $22.4 \%$ of the total volume of fixed assets of Russia; transport accounted for $18.7 \%$ of total investment. The main documents regulating the key strategic areas of transport development in Russia are the 'Transport Strategy of the Russian Fede- ration for the period until 2030', federal program 'Development of the Transport System of Russia (2010-2021),' 'Development Strategy of the Russian Railways until 2030', program 'Russian Automobile Roads in the Long Term (2010-2020)', and so on.

Regional transport infrastructure, ensuring the territorial integrity of the region, is an important element of the system of national economy and economic security (Lyutov, 2017). Transport is one of the largest basic sectors of the economy and an important component of infrastructure, which provides conditions for economic growth and contributes to national and regional prosperity. A region with developed transport infrastructure is in a relatively better position than its less successful counterparts. Moreover, developed transport infrastructure also facilitates the region's achievement of its strategic and tactical goals and allows it to optimize the use of all types of resources (Kudryavtsev \& Tarasenko, 2014).

The fuel and energy infrastructure performs such functions as providing people and enterprises with electricity and fuel and ensuring the energy-related and economic security of the country and regions. It also serves as a source of revenue for state and regional budgets. Moreover, its positive impact on regional growth is achieved due to the spatial effects that go beyond the boundaries of individual regions (Maliy \& Gusev, 2010).

The construction infrastructure participates in the creation of fixed assets and their expanded reproduction, implementation of housing construction programs, creating conditions for the development of the production and non-production sphere of the region.

The financial infrastructure, in its turn, ensures the consolidation of financial resources, their rational allocation and use, creating a favorable investment climate in the region.

The main function of the social infrastructure is to satisfy people's needs and create conditions for expanded reproduction of labor and creative potential of the region's population. This function largely depends on the quality of life in the region as well as the development of the real sector, since social infrastructure is 'the main factor in the formation of human capital that creates labor products' (Tikhonovich, 2012). The social infrastructure of a region includes health care, education and culture, public catering and consumer services, housing and communal services, and so on.

For optimal decision- and policy-making in a region, it is necessary to assess the actual state of 
its infrastructure against other regions (Kudryavtsev \& Tarasenko, 2014), which requires a set of appropriate indicators. Depending on the goal, objectives, and time interval of the study, partial, general and integral, static and dynamic indicators are calculated.

There are particular indicators reflecting the availability of individual elements of infrastructure in a region, while there are also consolidated indicators that characterize specific types of infrastructure and integrated indicators that reflect the state of infrastructure as a whole. Thus, in accordance with the types of infrastructure, it is possible to identify general indicators characterizing economic, financial, social and other types of infrastructure in a region. General indicators are based on particular indicators that characterize the availability of elements of specific types of infrastructure in the region. Static indicators are used to assess the state of infrastructure in the current period, while dynamic indicators reflect its changes in time. Both static and dynamic indicators can be partial, general or integral.

\section{Methodology and data}

To calculate indicators and assess their impact on economic growth and the quality of life in a region, we have formulated the following methodological principles:

- substantiation of hypotheses about the nature and aspects of the infrastructure's impact on regional development, regarding specific types of infrastructure and in general;

- selection of baseline indicators, their normalization and grouping by infrastructure type, formation of a data base;

- calculation of static and dynamic indicators characterizing regional infrastructure;

- comparative analysis and rating of regions regarding their infrastructure in general and its specific types;

- econometric analysis of the impact of infrastructure-related factors on economic growth and quality of life in a region;

- cluster analysis of the regions based on the calculated indicators;

- identification of the most typical problems of infrastructure development and the corresponding priority areas of strategic development.

In our study, the choice of initial (particular) indicators was determined, as already noted above, by the principles of complexity, consistency, representativeness, reliability and comparabil- ity. The indicators also corresponded to specific types of infrastructure.

Aggregated, static indicators are formed by using normalized particular indicators that characterize elements of a specific type of infrastructure.

Normalization of individual indicators is done by using the following formula:

$$
N_{i j}^{R}=\frac{N_{i j}-N_{i}^{\min }}{N_{i}^{\max }-N_{i}^{\min }},
$$

where $N_{i j}^{R}$ is the normalized estimation of the $i$-th indicator for the $j$-th region;

$N_{i j}$ is the value of the $i$-th particular indicator for the $j$-th region;

$N_{i}^{\min }, N_{i}^{\max }$ are the lowest and highest values of the $i$-th indicator for all regions;

$i, j$ are the sequential numbers of the indicator and the region, respectively.

Aggregate static indicators are calculated as arithmetic means of normalized indicators, while aggregate dynamic indicators are calculated as geometric means of indexes of private indicators $\left(I_{i j}\right)$ for each type of infrastructure. Similarly, integral static indicators are calculated as arithmetic means and integral dynamic indicators are calculated as geometric means of aggregate indicators for all types of infrastructure.

The $k$-means method was used to classify Russian regions depending on the values of aggregate and integral indicators of specific types of infrastructure. Cluster analysis is necessary to identify problems of infrastructure development that are characteristic of certain groups of regions, assess the development of different types of infrastructure in each region, and assess whether the existing infrastructure meets the needs of the real sector and the population. The use of this method makes it possible to identify the weaknesses and comparative advantages of regions in socio-economic development regarding their infrastructure, which is necessary for strategic decision-making.

The methodological recommendations were tested by the authors in relation to Russian regions. To calculate the indicators, a data base was created drawing from the official Rosstat data. The initial data for the econometric analysis is presented as a panel for Russian regions for 19992015. To calculate static and dynamic indicators, we used the data from official statistics for 5 years (2012-2016). 


\section{Results}

The results of the regression analysis (Ignatyeva et al., 2018) have shown that the most significant factors that positively affect GRP per capita are fixed capital investment and the share of university graduates in the total population. This conclusion confirms the importance of investment and education as factors of regional socio-economic development.

The road density index had a very significant impact on GRP per capita, in contrast to the railway density index. This can be explained by the following features of rail transport - less flexible schedule of cargo delivery compared to road transport, possible distance of the tracks from the points of cargo delivery, longer transportation times, and "bottlenecks".

Intervals of values of static indicators of infrastructure development for 2012-2016 are shown in Table 1 .

Our calculations of statistic indicators have shown that Moscow is the leader in terms of infrastructure development among Russian regions. In all aggregate indicators, as well as in the integral indicator and the volume of GRP per capita, it surpasses other Russian regions. Moscow is also the absolute leader in terms of railways and roads with solid cover, which provided a relatively high level of this region in the aggregate indicator of productive-economic infrastructure. Relatively high levels in the indicators characterizing productive-economic, economic and financial infrastructure and in the integral indicator are typical of the Khanty-Mansiysk, Yamalo-Nenets and Nenets Autonomous okrugs, Kamchatka and other regions rich in natural and mineral resources. The group of high achieving regions also includes Sverdlovsk region, St. Petersburg, Moscow region, Leningrad region, the Republic of Tatarstan, Kaliningrad region and some others.

The medium level in aggregate indicators of infrastructure development is characteristic of Belgorod, Lipetsk, Vologda, Murmansk, Perm and Novgorod regions. The lowest levels in all the indicators are found in Altai, Adygea, Kalmykia,
Astrakhan region, Dagestan, Ingushetia, the Kabardino-Balkar, Karachay-Cherkess and Chechen Republic. The relatively low level of infrastructure development in these regions impedes the development of the real economy and improvement of the quality of life. These regions are also characterized by the lowest levels of GRP per capita.

We used the indicators of productive-economic, financial and social infrastructure for cluster analysis and grouping of Russian regions. In this article, we discuss primarily the results of cluster analysis based on dynamic indicators (for more on typological groupings of Russian regions based on static indicators, see Ignatieva et al, 2019)

As a result of cluster analysis, 6 typological groups (clusters) of Russian regions were identified. Table 2 illustrates the comparative characteristics of these groups based on the aggregate dynamic indicators for three types of infrastructure - industrial, financial and social. The table also shows integrated static indicators to show the dynamics of infrastructure development in regions.

The figure shows significant discrepancies in regional infrastructure development in Russia. The first group constitutes the largest share (45\%), the fourth group accounts for $24 \%$, and the fifth, for $15 \%$. The shares of the second, third and sixth groups were $7 \%, 2 \%$ and $7 \%$, respectively.

Let's look at some characteristics of each cluster.

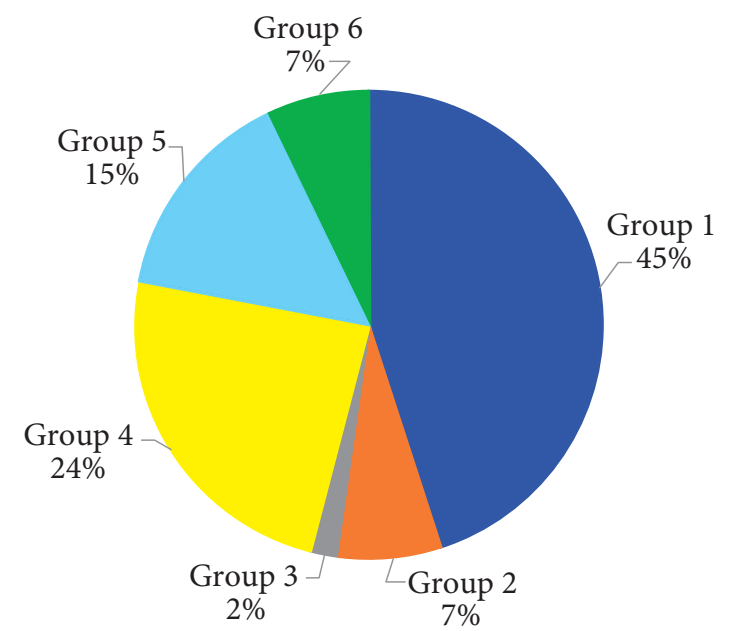

Figure 1. Distribution of Russian regions based on dynamic indicators of infrastructure development

Table 1

Intervals of values of static indicators of infrastructure development in Russian regions

\begin{tabular}{|c|c|c|c|c|c|c|}
\hline \multirow[t]{2}{*}{ № } & \multirow[t]{2}{*}{ Value of indicators } & \multicolumn{3}{|c|}{ Type of infrastructure } & \multirow{2}{*}{$\begin{array}{l}\text { Integrated } \\
\text { indicator }\end{array}$} & \multirow{2}{*}{$\begin{array}{l}\text { GRP per capita, } \\
\text { RUB }\end{array}$} \\
\hline & & Production-economic & Social & Financial & & \\
\hline 1 & Maximum value & 0,027 & 0,128 & 0,003 & 0,088 & 106756,6 \\
\hline 2 & Minimal value & 0,664 & 0,610 & 0,686 & 0,595 & 5821559,8 \\
\hline
\end{tabular}

Source: the authors' calculations are based on statistical data (Rosstat). 
As the Table illustrates, the highest values in dynamic indicators are found in the third group of regions (especially in financial indicators), although their infrastructure development is at the medium level (Bashkortostan) or somewhat lower (Mari El). The negative dynamics of infrastructural development (or the lowest figures in dynamic indicators) is typical of the sixth group, which includes both regions with a high level of infrastructure development (Tatarstan, Perm Krai) and regions with a relatively low level of infrastructure development (Karachay-Cherkess Republic, Astrakhan region).

The relatively stable dynamics of infrastructure development was observed in groups 1, 2, 4 , and 5 , but each of these groups had its own characteristics. The financial infrastructure in the regions of the second and fifth groups developed relatively dynamically at relatively low starting levels. The stable dynamics of productive-economic and financial infrastructure development is characteristic of the regions of the first group, which is also the largest, including regions whose current level of development for these types of infrastructure is quite high (Moscow, Saint Petersburg, Khanty-Mansi Autonomous Okrug).

Such regions as Moscow, Tatarstan, and the Yamalo-Nenets Autonomous Okrug with high levels of static indicators have demonstrated low levels in the dynamic indicators of social infrastructure development. In a number of regions, the opposite picture was observed - social infra-

Table 2

Comparative characteristics of groups (clusters) of Russian regions based on aggregate dynamic indicators

\begin{tabular}{|c|c|c|c|c|}
\hline \multirow{2}{*}{ Values } & \multicolumn{3}{|c|}{ General dynamic indicators by type of infrastructure } & $\begin{array}{c}\text { Integral } \\
\text { static indicator }\end{array}$ \\
\cline { 2 - 4 } & Productive-economic & Social & Financial & . \\
\hline
\end{tabular}

Group 1 (37): Belgorod region, Vladimir region, Voronezh region, Ivanovo region, Kaluga region, Kostroma region, Kursk region, Moscow region, Orel region, Smolensk region, Tver region, Yaroslavl region, Moscow, Nenets Autonomous Okrug, Murmansk region, Novgorod region, Saint Petersburg, Stavropol territory, Republic of Mordovia, Chuvash Republic, Kurgan oblast, Khanty-Mansi Autonomous Okrug - Yugra, Yamalo-Nenets Autonomous Okrug, Tyumen region, Chelyabinsk region, Republic of Altai, Republic of Buryatia, Republic of Tuva, Republic of Khakassia, Altai Krai, Zabaykalsky Krai, Krasnoyarsk Krai, Novosibirsk region, Tomsk region, Republic of Sakha (Yakutia), Kamchatka territory, Sakhalin region.

\begin{tabular}{|l|r|r|r|r|}
\hline Maximum & 1,464 & 1,417 & 0,979 & 0,595 \\
\hline Minimum & 0,826 & 1,122 & 0,701 & 0,157 \\
\hline Mean & 1,034 & 1,251 & 0,877 & 0,256 \\
\hline
\end{tabular}

Group 2 (6): Krasnodar territory, Volgograd region, Rostov region, Udmurt Republic, Kirov region, Ulyanovsk region

\begin{tabular}{|l|r|r|r|r|}
\hline Maximum & 1,479 & 2,799 & 1,081 & 0,350 \\
\hline Minimum & 1,278 & 2,040 & 0,934 & 0,195 \\
\hline Mean & 1,375 & 2,246 & 1,004 & 0,253 \\
\hline \multicolumn{5}{|c|}{ Group 3 (2): Republic of Bashkortostan, Republic of Mari El } \\
\hline Maximum & 2,326 & 4,652 & 1,132 & 0,233 \\
\hline Minimum & 2,071 & 4,101 & 1,106 & 0,182 \\
\hline Mean & 2,199 & 4,377 & 1,119 & 0,207 \\
\hline
\end{tabular}

Group 4 (20): Ryazan region, Tula region, Republic of Karelia, Komi Republic, Arkhangelsk region, Vologda region,

Kaliningrad region, Leningrad region, Pskov region, Republic of Adygea, Republic of Kalmykia, Republic of Ingushetia, Republic of North Ossetia, Kabardino-Balkar Republic, Sverdlovsk region, Kemerovo region, Omsk region, Primorye Krai,

\begin{tabular}{|l|r|r|r|r|}
\hline \multicolumn{7}{|c|}{ Jewish Autonomous Okrug, Chukotka Autonomous Okrug } \\
\hline Maximum & 1,142 & 1,143 & 1,163 & 0,357 \\
\hline Minimum & 0,782 & 0,913 & 0,816 & 0,088 \\
\hline Mean & 0,976 & 1,062 & 0,944 & 0,217 \\
\hline
\end{tabular}

Group 5 (12): Bryansk region, Lipetsk region, Tambov region, Republic of Dagestan, Chechen Republic, Orenburg region,

\begin{tabular}{|l|r|r|r|r|}
\multicolumn{5}{|c|}{ Penza region, Saratov region, Irkutsk region, Khabarovsk Krai, Amur region, Magadan region. } \\
\hline Maximum & 1,189 & 1,832 & 1,083 & 0,367 \\
\hline Minimum & 0,954 & 1,436 & 0,864 & 0,148 \\
\hline Mean & 1,024 & 1,588 & 0,946 & 0,231 \\
\hline
\end{tabular}

Group 6 (6): Astrakhan region, Karachay-Cherkess Republic, Republic of Tatarstan, Perm region, Nizhny Novgorod region,

\begin{tabular}{|l|r|r|r|r|}
\hline \multicolumn{5}{|c|}{ Samara region. } \\
Maximum & 1,041 & 0,854 & 0,784 & 0,284 \\
\hline Minimum & 0,495 & 0,403 & 0,663 & 0,111 \\
\hline Mean & 0,694 & 0,630 & 0,733 & 0,217 \\
\hline
\end{tabular}

Source: the authors' calculations are based on statistical data (Rosstat). 
structure developed more dynamically in regions with low initial levels of development (Chechnya, North Ossetia, Mari El, and Tambov region). The only exceptions were the Chukotka Autonomous Okrug and Leningrad region, characterized by relatively high dynamic estimates with high initial levels of infrastructure development.

Thus, the calculation of static and dynamic indicators allowed us to compare the levels and dynamics of various types of infrastructure, which is necessary to identify the threats to economic security associated with negative trends in infrastructure development and determining the prospects for infrastructure development in Russian regions.

According to Rosstat, depreciation of fixed assets in transport at the end of 2018 amounted to $39.7 \%$ and in construction, $48.9 \%$. To modernize and update fixed assets and introduce new technologies, it is necessary to attract investment, which includes investment from institutional investors (banks, pension funds, insurance companies) through public-private partnership (PPP) mechanisms. This opens new opportunities for investors, developers and consumers as PPP mechanisms allow to combine the potential of the state and business. Currently, the most promising PPP projects in the transport sector are implemented in Moscow and St. Petersburg, since these regions have most advantages in terms of road density, financial infrastructure development, and the level of income (Ofin, 2016).

To expand the scope and improve the efficiency of PPP mechanisms in Russian regions, it may be useful to study the foreign experience of using such financing schemes in infrastructure development. For example, in Australia, 10-15\% of total investment in infrastructure by the mid-2000s was carried out at the expense of public-private partnerships (Gilmour et al., 2010).

The bulk of this investment was primarily intended for the creation of economic infrastructure, although in some cases social infrastructure was also created. There is a foreign practice of attracting investment to create and develop infrastructure facilities by issuing infrastructure bonds. In the United States, pension funds are invested in infrastructure bonds to finance infrastructure projects, with preference given to municipal loans. The main issuers of infrastructure bonds in India are banks, and in Chile - concessionaires, and concession projects using infrastructure bonds enjoy the highest credit ratings (Ivanov, 2011).
In Russia, infrastructure bonds worth about 50 billion rubles were issued by JSC 'Western High-Speed Diameter', JSC 'Main Road', and LLC 'North-Western Concession Company'. The potential amount of funds of the Russian pension system invested in infrastructure development may be from $\$ 3.5$ to $\$ 7.0$ billion in the short term, with the possibility of an almost two-fold increase in the medium term. The participation of the state as an issuer of infrastructure bonds guarantees a reduction in risk and an increase in the investment attractiveness of regional and municipal infrastructure projects (Stuart, 2017).

As we have noted above, the development of some types of infrastructure leads to the development of other types of infrastructure, i.e. balanced development of infrastructure is an important condition for its effective functioning. One of the key factors of infrastructure development in regions is the efficient performance of the financial infrastructure, since an important area for implementing investment projects in the field of productive economic and social infrastructure is to attract funds from institutional investors (banks, pension funds, insurance companies) to finance the creation of new and improve the already existing facilities.

\section{Conclusions}

Problems of infrastructure development in Russian regions should be solved comprehensively as the development of infrastructure affects all social and economic processes and is necessary to create conditions for the development of the real sector, rational use of material and labor resources. Infrastructure is also essential to provide opportunities for personal growth, improvement of the demographic situation and the quality of life. The methodological principles described in this article can be used to assess the impact of infrastructure on GRP per capita as a general indicator of socio-economic development, assess the comparative advantages of regions related to the state of their infrastructure, and identify strong and weak aspects in infrastructure development.

The methodological principles and tools have been tested by using the data for Russian regions, which shows the practical significance of this approach. As a result, we identified the most typical problems faced by Russian regions. These problems should be taken into account in strategic decision- and policy-making. As our regression and correlation analysis has shown, 
one of the major challenges in this respect is to ensure a more balanced development of the country in terms of infrastructure. Investment is crucial for the implementation of infrastructure projects, equipment modernization, and digitalization of infrastructure sectors. This will create incentives for the development of the real sector, social sphere and, in the long run, will improve the quality of life in the regions. As Russian and international experience has shown, special attention should be paid to the enhancement of the efficiency of investment projects through the active use of PPP mechanisms.

Further research prospects, in our opinion, consist in a more detailed analysis based on the proposed static and dynamic indicators of infrastructure development and its impact on socio-economic development, with the identification of leaders and laggards, monitoring infrastructure development in regions where large infrastructure projects are being implemented, including using PPP mechanisms.

\section{References}

Cantos, P., Gumbau-Albert, M., \& Maudos, J. (2005) Transport infrastructures and regional growth: evidence of the Spanish case: Universitat de Valencia, Instituto Valenciano de Investigaciones Economicas, Retrieved from https://mpra.ub.uni-muenchen.de/15261/1/MPRA paper_15261.pdf

Chen, Y., \& Fang, Z. (2018). Industrial electricity consumption, human capital investment and economic growth in Chinese cities. Economic Modelling, 69, 205-219.

Efimova, E.G. (2009) The role of transport in the economic development of the region: international aspect. Bulletin of St. Petersburg State University. Series 5. 1, 77-85.

Gilmour T., Wiesel I., Pinnegar S., Loosemore M. (2010) Social infrastructure partnerships: a firm rock in a storm?. Journal of Financial Management of Property and Construction, 15(3), 247-259, doi: $10.1108 / 13664381011087506$

Ignatieva, E.D., Mariev, O.S., \& Serkova, A.E. (2019) A methodological approach to assessing the impact of infrastructure provision on the socio-economic development of the Russian regions. Perm University Herald. Series: Economics, 14(3), 434-447.

Ignatyeva, E.D., Mariev, O.S., \& Serkova, A.E. (2018) Influence of infrastructure factors on the development of the real sector of the economy and the quality of life of the population of the Russian regions. Economics and Entrepreneurship, 3(92), 573-578.

Ivanov, M.E. (2011). Activation of long-term investments for the construction and modernization of regional infrastructure through infrastructure bonds. Financial analytics: problems and solutions, (41).

Kazakova, M.V., \& Pospelova, E.A. (2017) The quality of infrastructure as one of the limitations of economic growth: a comparative analysis of Russia and the countries of the world. Economic relations, 4(3), 247-268.

Kiselev, S.V., \& Tkachev, S.V. (2015) Economic-mathematical model for assessing the impact of social infrastructure services on the economic development of the region. Fundamental Research, 8-2, 385-391. Retrieved from http://fundamental-research.ru/ru/article/view?id=38906

Kudryavtsev, A.M., \& Tarasenko, A.A. (2014) Methodological approach to assessing the development of transport infrastructure in the region. Fundamental research, 6-4, 789-793. Retrieved from https://fundamental-research.ru/ru/article/view?id=34241

Lyutov, M.A. (2017) Improving the development of transport infrastructure of the region (city). Scientific Journal, 7(20), 104-113.

Malafeev, N.S., \& Baskakova, I.V. (2017) Empiric value of share of infrastructural capital in development of region. Economics of region, 13(3), 777-788. doi: 10.17059/2017-3-11

Maliy, V.I., \& Gusev, V.V. (2010) The impact of energy enterprises on the socio-economic development and competitiveness of the region (on the example of the Saratov region). Tomsk State University Bulletin. Philosophy. Sociology. Political science, 1(9), 137-153.

Melnikov, E.P., Chornous, O.I., \& Vezelev, I.I. (2019) Evaluation of infrastructural support of the economic security of motor transport of the Russian Federation. Bulletin of UrFU. Series Economics and Management, 18(2), 313-332.

Ofin, V.P. (2016) Features of the implementation of public-private partnership projects in the transport infrastructure. News of St. Petersburg State University, 6(102), 19-23. 
Owualah, S. (1987) Providing the necessary economic infrastructures for small businesses: whose responsibility? International Small Business Journal, 6, 10-30.

Pchelintsev, O.S. (2004) Regional economy in the system of sustainable development. Institute of Economic Forecasting RAS. M.: Nauka, 258.

Roskruge, M., Grimes, A., McCann, P., \& Poot, J. (2011) Social capital and regional social infrastructure investment: evidence from New Zealand, International Regional Science Review, 35, 3-25.

Shvetsov, K.V., Sorokozherdyev, K.G., \& Pakhomova, P.M. (2018) Analysis of the impact of the infrastructure of the Nenets Autonomous Okrug on the socio-economic development of the region. Bulletin of Ural Federal University. Series Economics and Management, 17(2), 263-282.

Stuart, E. (2017, August 24). The illusion of infrastructure bonds. Why did the focus fail? Forbes Website. Retrieved from https://www.forbes.ru/finansy-i-investicii/349401-illyuziya-infrastrukturnyh-obligaciy-pochemu-fokus-ne-udalsya

Tikhonovich, E.A. (2012) The influence of social infrastructure on the reproduction of human capital. Bulletin of Volgograd State University. Series 3. Economics. Ecology, 1(20), 22-28.

Tiwari, A.K. (2008) Economic infrastructure and agricultural development in Himachal Pradesh: A district level analysis. Social Change, 38, 245-262.

Wai, S.H., Yusof, A. Md, Ismail, S., \& Ng, C.A. (2013) Exploring success factors of social infrastructure projects in Malaysia. International Journal of Engineering Business Management, 5 doi: $\underline{10.5772 / 55659}$.

Wang, C., Lim, M. K., Zhang, X., Zhao, L., \& Lee, P.T.W. (2020). Railway and road infrastructure in the Belt and Road Initiative countries: Estimating the impact of transport infrastructure on economic growth. Transportation Research Part A: Policy and Practice, 134, 288-307.

\section{Information about the authors}

Elena D. Ignatieva - Cand.Sc. (Economics), senior researcher, Institute of Economics of the Ural Branch of the Russian Academy of Sciences (29, Moskovskaya str., Yekaterinburg, 620014, Russia); e-mail: elen_i99@mail.ru

Oleg S. Mariev - Cand.Sc. (Economics), associate professor, Head of the Department of Econometrics and Statistics, Ural Federal University (19, Mira str., Yekaterinburg, 620002, Russia); senior researcher, Institute of Economics of the Ural Branch of the Russian Academy of Sciences (29, Moskovskaya str., Yekaterinburg, 620014, Russia); e-mail: olegmariev@mail.ru

Alla Ye. Serkova - leading economist, Institute of Economics of the Ural Branch of the Russian Academy of Sciences (29, Moskovskaya str., Yekaterinburg, 620014, Russia); e-mail: muccio@bk.ru

ARTICLE INFO: received February 9, 2020; accepted May 10, 2020

\section{Информация об авторах}

Игнатьева Елена Дмитриевна - кандидат экономических наук, старший научный сотрудник Института экономики Уральского отделения Российской академии наук (620014, г. Екатеринбург, ул. Московская, 29); e-mail: elen_i99@mail.ru

Мариев Олег Святославович - кандидат экономических, доцент, заведующий кафедрой эконометрики и статистики Уральского федерального университета (620002, Россия, г. Екатеринбург, ул. Мира, 19); старший научный сотрудник Института экомоники Уральского отделения Российской академии наук (620014, г. Екатеринбург, ул. Московская, 29); e-mail: olegmariev@mail.ru

Серкова Алла Евгеньевна - ведущий экономист Института экономики Уральского отделения Российской академии наук (620014, г. Екатеринбург, ул. Московская, 29); e-mail: muccio@bk.ru

ИНФОРМАЦИЯ О СТАТЬЕ: дата поступления 9 февраля 2020 г.; дата принятия к печати 10 мая 2020 г. 